\title{
Measuring Service Quality in the Banking Industry: A Hong Kong Based Study
}

\author{
Mei Mei Lau \\ The Hong Kong Polytechnic University \\ E-Mail: spmay@speed-polyu.edu.hk \\ Ronnie Cheung \\ University of South Australia \\ E-Mail: ccheung@acm.org \\ Aris Y. C. Lam \\ The Hong Kong Polytechnic University \\ E-Mail: sparis@speed-polyu.edu.hk \\ Yuen Ting Chu \\ The Hong Kong Polytechnic University \\ E-Mail: fairyland410@yahoo.com.hk
}

\begin{abstract}
The goal of this study is to identify the interrelationships between service quality, customer satisfaction and customer loyalty in the retail banking sector in Hong Kong. The study also aims to find out the most important attributes of service quality in retail banks, which can be used to evaluate the characteristics of banking service quality as perceived by customers. A sample of 119 retail banking customers was drawn from the Hong Kong and Shanghai Banking Corporation (HSBC) in Hong Kong. The questionnaire developed for this study was based on a SERVQUAL model that identified the influence of five dimensions (i.e. tangibility, responsibility, reliability, assurance and empathy) in banking service environments on customer satisfaction. The results indicate that the five SERVQUAL dimensions have a positive influence on customer satisfaction. Tangibility, responsibility, reliability and assurance were more significant in contributing to customer satisfaction, while empathy was the least significant. This study suggests that SERVQUAL is a suitable instrument for measuring service quality in the retail banking sectors in Hong Kong. Hence, banking
\end{abstract}


industry practitioners can consider this instrument as a tool to assess and help improve their service quality.

Keywords: SERVQUAL, Service Quality, Customer Satisfaction, Customer Loyalty, Banking Industry, Hong Kong

\section{INTRODUCTION}

Banks play an important and active role in the financial and economic development of a country. An effective banking system greatly influences the growth of a country in various sectors of the economy. Practitioners in the banking industry face a large number of complex challenges in the global marketplace. It is crucial for banks to better understand changing customer needs and adopt the latest information technology system in order to compete more effectively with global organizations (Malhotra \& Mukherjee, 2004).

Hong Kong has been enjoying strong economic growth in the Asia Pacific region and is one of the key international financial centers in the world. Indeed, the success of the banking system supports currency stability, which is the primary objective of the monetary policy in Hong Kong. Hong Kong is one of the top ten largest banking centers in the world (The Standard, 2011). The sector contributed over 15\% of Hong Kong's nominal GDP in 2010, and the total employment is around 80,000 (Censtatd, 2011a, b). Currently, 172 banks are now operating in Hong Kong, which is a relatively large number compared with many international cities (The Hong Kong Association of Banks, 2011). However, globalization has altered customer behavior in regards to banking services, and the operating environment for banking industry has become more dynamic and competitive. The emergent of new forms of banking services such as automated teller machines, internet banking, and phone banking as well as the maturing financial market and global competition accelerate the need for bankers to explore the importance of customer satisfaction and customer loyalty.

Established in 1865, the Hong Kong and Shanghai Banking Corporation Limited (HSBC) finances the growing trade between Europe, India and China. Headquartered in London since 1993, the HSBC group is now operating in five regions: Europe, Hong Kong, Asia Pacific (including the Middle East and Africa), North America, and South America (HSBC, 2011). HSBC has an immense operational infrastructure in Asia and provides banking and financial services around the world. According to a composite measure by Forbes magazine, HSBC is the world's second-largest banking and financial services group and was the second-largest public company in 2010 
(Forbes, 2011). In the twenty-first century, HSBC has renewed its focus on growing its business in China both organically and through a series of strategic partnerships. Hong Kong still remains its target group and continues to be a significant source of revenue. Therefore, customers of HSBC are chosen as the focus for this study.

A vast number of studies were used to identify the significance of service quality. Good service quality is generally regarded as a way to retain existing customers and acquire new ones, reduce costs, enhance corporate image, generate positive word-of-mouth recommendation, and improve profitability (Berry et al., 1989; Cronin et al., 2000; Kang \& James, 2004; Reichheld \& Sasser, 1990; Rust \& Zahorik, 1993; Yoon \& Suh, 2004). As the global world has suffered from financial depression in recent years, it is essential for banks to establish a sturdy and solid loyal customer base to weather tougher economies and more intense competition. The practice of excellent service quality integrated with consumer products is a powerful generator to cater to customers' needs and engage with them. Considering that many banks offer undifferentiated products in a rival marketplace, banks are paying more attention to service quality in order to gain a competitive advantage. Banks that master service quality can gain a competitive edge in terms of higher revenue, customer loyalty and customer retention (Kumar et al., 2010). Thus, this study has two main objectives: to find the interrelationships between service quality, customer satisfaction and customer loyalty in the banking sector in Hong Kong and to identify the most important attributes of service quality considered by customers in the banking sector.

This paper has four sections. First, we present the theoretical background of service quality, customer satisfaction and loyalty and then provide a research model and hypotheses to demonstrate relationships of the variables. Next, we describe our methodology including research design and data collection. A survey questionnaire was administered to collect data from HSBC customers. Subsequently, we identify the relationships between each variable from the findings. Finally, we conclude with recommendations on strategies for practitioners in the banking industries and future research directions.

\section{LITERATURE REVIEW AND THEORETICAL FRAMEWORK}

A successful business organization must acquire new customers and get existing customers to continue consuming the products and services provided rather than turning to competitors. Service quality is regarded as a critical success factor for organizations to differentiate from competitors. Many studies have been conducted to determine the factors of service quality. For example, researchers have found that 
customer satisfaction can lead to customer loyalty (Caruana, 2002; Caruana et al., 2000). Loyal customers will tend to repurchase from the same service provider (Ryan et al., 1999); in turn, firm revenue will increase in the long run. Variations in service performance may provide opportunities to influence customers' perceived value, satisfaction and loyalty. Thus, the relationships between these three aspects can provide bankers with insights into both tangible and intangible service improvements, especially to develop a competitive edge in the Hong Kong banking industry. This research employs the SERVQUAL scale to measure customer satisfaction and loyalty in the banking industry (Parasuraman et al., 1988).

\section{Service Quality}

Service quality is defined as the degree of discrepancy between customers' normative expectations for service and their perceptions of service performance (Parasuraman et al., 1985). Consumers usually shop at specific stores, because they like the service provided and they are assured of certain service privileges; thus, the performance of salespeople stimulates bonding through trust between them and customers, which affects the latter's perception of the store or brand (Lau et al., 2006; Leung \& To, 2001). Service quality can be defined as meeting the needs and expectations of the customer (Smith, 1998). The definition of service quality can be extended to the overall evaluation of a specific service with ten service quality dimensions: tangibles, reliability, responsiveness, competence, courtesy, credibility, security, access, communication and understanding/knowing the customer (Parasuraman et al., 1985, 1988). These ten dimensions were yielded from a questionnaire with 97 items (Parasuraman et al., 1988). Zeithaml, Parasuraman and Berry (1990) refined the ten dimensions into five to measure customer's perceived value of service quality, which is known as SERVQUAL. This SERVQUAL adopts the meeting expectations paradigm to measure service against firms (Ladhari, 2009).

\section{SERVQUAL Dimensions in Relation to the Banking Sector}

Five dimensions of SERVQUAL have been developed for the service sectors: tangibility, reliability, assurance, responsiveness, and empathy (Van Iwaarden et al., 2003). Tangibility represents physical facilities, equipment and appearance of personnel. Examples of the tangible factor related to banks include comfortable store designs, up-to-date equipment for customer use and sufficient staff to provide service. These aspects are important for retail banks, because there are extensive face-to-face contacts between a customer and an employee. Therefore, maintaining a professional 
and comfortable store environment can increase customer satisfaction. The next dimension is responsiveness, which represents the willingness to help customers and provide prompt service. In order to be helpful and responsive to customers, HSBC, for example, has incorporated the statement due date on SMS alerts sent to cardholders (HSBC, 2011). This personal service aims to enhance customer satisfaction. Reliability means the ability to perform the promised service dependably and accurately. The major reason for customers to choose banks for investment funds is because of the dependability and reputation of banks. Banks always promise customers a high level of security during transactions. Banking service can increase customers' confidence and trust if employees are able to provide appropriate service to each customer. For instance, understanding the needs of each individual customer, such as knowing the customers' expected retirement age, annual income, and hobbies are required to help provide a good match of insurance and fund products for customers. Assurance is the knowledge and courtesy of employees and their ability to inspire trust and confidence. Bank commitments are important, as customers may save a large sum of money in banks. For complicated products such as insurance, funds, and margins, employees must provide a clear explanation of each product to customers, so that customers can feel confident about the services provided by banks. The final dimension is empathy, which represents the individualized attention that firms provide to its customers. Employees who show understanding of customer needs and are knowledgeable to solve customer problems are success factors for the service industry. Friendly customer service pleases customers when they walk into a bank. The purpose of this dimension is to retain customers to keep using the bank service (Van Iwaarden et al., 2003).

The applicability of the service quality measure was tested in the retail banking industry in India (Angur et al., 1999). This research was conducted to measure the overall service quality perceived by customers of two major banks in India using the SERVQUAL model. The data indicated that dimensions were not equally important in explaining variances in the overall service quality. Responsiveness and reliability were the most important dimensions, followed by the empathy and tangible dimensions; assurance appeared to be the least important. It was concluded that SERVQUAL is the best model to measure service quality in the banking industry (Angur et al., 1999). In summary, SERVQUAL is a proper assessment tool to measure service quality in the retail banking industry. 


\section{Customer Satisfaction}

Customer satisfaction provides an essential link between cumulative purchase and post-purchase phenomena in terms of attitude change, repeat purchase and brand loyalty (Churchill \& Surprenant, 1982). Service quality has a positive influence on customer satisfaction (Yee et al., 2010). Customer satisfaction is defined as the attitude resulting from what customers believe should happen (expectations) compared to what they believe did happen (performance perception) (Neal, 1998). Satisfaction reinforces quality perception and drives repeat purchases. Zaim, Bayyurt, and Zaim (2010) found that tangibility, reliability and empathy are important for customer satisfaction, but Mengi (2009) found that responsiveness and assurance are more important. Siddiqi (2010) examined the applicability of service quality of retail banking industry in Bangladesh and found that service quality is positively correlated with customer satisfaction; empathy had the highest positive correlation with customer satisfaction, followed by assurance and tangibility. On the other hand, Lo, Osman, Ramayah and Rahim (2010) found that empathy and assurance had the highest influence on customer satisfaction in the Malaysian retail banking industry. Arasli, Smadi and Katircioglu (2005) found that reliability had the highest impact on customer satisfaction. A number of studies have identified the dimensions of service quality as the antecedents of customer satisfaction. Relatively few studies have investigated service quality in the retail banking sector in Hong Kong. Based on the above studies, it is reasonable to hypothesize the following:

H1: Tangibility has a positive influence on customer satisfaction.

H2: Responsiveness has a positive influence on customer satisfaction.

H3: Reliability has a positive influence on customer satisfaction.

H4: Assurance has a positive influence on customer satisfaction.

H5: Empathy has a positive influence on customer satisfaction.

\section{Customer Loyalty}

Customer loyalty is an asset. Consumers are willing to pay more for a brand (Wernerfelt, 1991). Customer satisfaction is positively related to customer loyalty and organizational profits (Rust \& Zahorik, 1993). However, the cost of attracting a new customer can be five times higher than the cost of keeping a current customer satisfied (Kotler \& Armstrong, 1999), because loyalty has to be developed over a period of time from a consistent record of meeting (and sometimes exceeding) customer expectations (Teich, 1997). Loyalty is a multi-dimensional construct that includes both positive and negative responses (Zeithaml et al., 1996). A loyal customer may 
not necessarily be a satisfied customer. A customer who continues to repurchase from a firm because he or she believes that there is no convenient alternative is not a loyal customer. Such customers may switch to another service provider when convenient alternatives become available, especially if he or she is not satisfied with the current provider. In contrast, customers exhibit repeat purchase behavior from a service provider when they possess a positive attitudinal disposition toward the provider and consider using only one provider when a need for this service exists (Gremler \& Brown, 1996). This satisfied customer may have the opportunity to choose another brand for trial or to purchase less frequently due to reduced need. Alternatively, he or she may continue to purchase because of high switching cost or convenience. Hence, maintaining a sustainable relationship with customers is the key to building a loyal customer base. We expect that if a customer is satisfied with a firm, service or product, then a greater level of customer loyalty can be achieved. Thus, the following hypothesis is offered:

H6: Customer satisfaction has a positive influence on customer loyalty.

From the existing literature discussed above, a theoretical framework was developed. This framework identifies the relationship among service quality, customer satisfaction and customer loyalty in the banking industry in Hong Kong. Three research questions are developed to address the influence of specific service quality dimensions on customer satisfaction, specific predictors that influence customer loyalty and the contribution of the SERVQUAL model in the retail banking industry. Then, six hypotheses are derived from these research questions. Figure 1 shows the framework suggesting six links among the seven constructs (i.e. tangibility, responsiveness, reliability, assurance, empathy, customer satisfaction, and customer loyalty).

\section{METHODS}

\section{Sampling and Data Collection}

The target population for this study is the local bank customers from HSBC in Hong Kong. HSBC is a world-renowned bank whose customers are perceived as reasonable representatives of the population. The sampling units consist of a heterogeneous population of the legal age to hold a savings and/or current account in HSBC. 


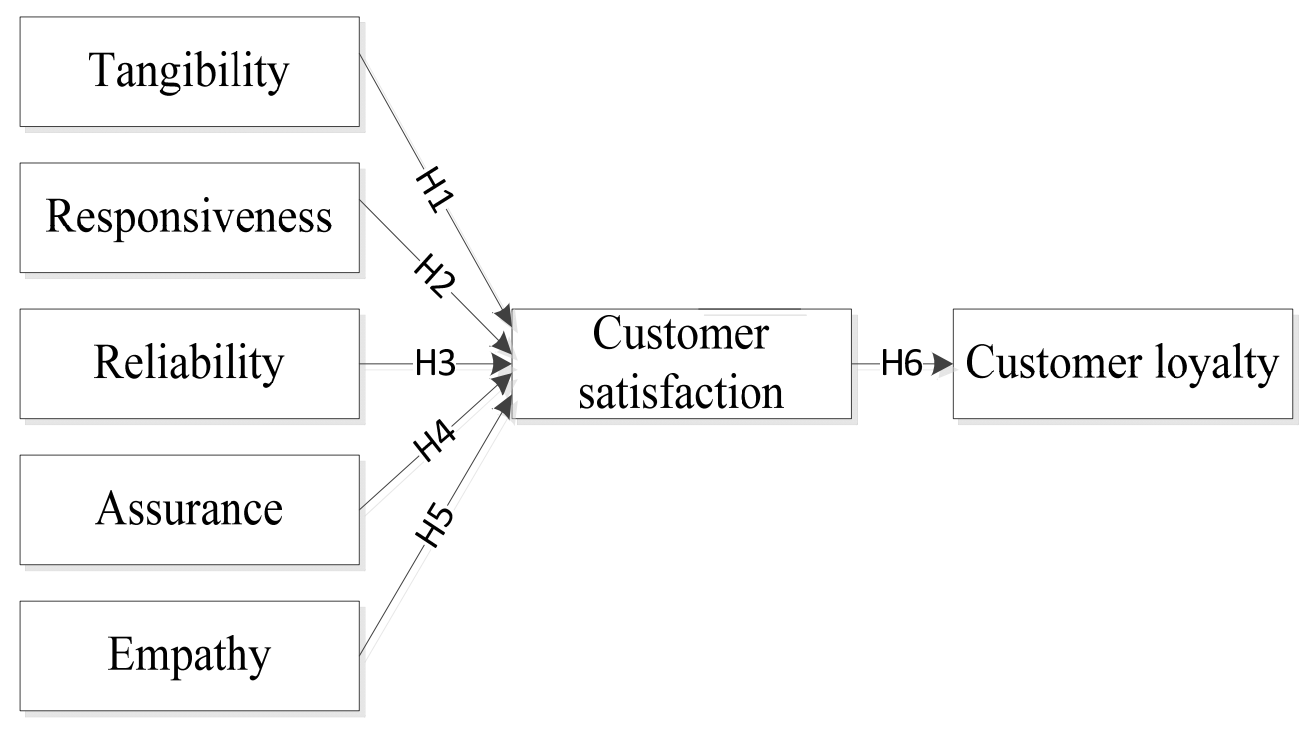

Figure 1 Theoretical Framework

A pilot study using in-depth interviews was conducted with 20 customers of HSBC. The purpose of this pilot study was to ensure that the structure was well defined and to minimize any possible errors. The developed questionnaire was reviewed by two experts in the field of quality research. Two of the respondents commented that the questionnaire was too long, which led to the improved version presented in this study. The final questionnaire consisted of 26 questions.

A self-administered survey was conducted. The respondents were demographically diverse customers of HSBC retail banking services who reside in Hong Kong. They received a hyperlink, which directed them to the Web site containing the questionnaire. They were asked to respond to the questionnaire electronically and to submit it online. This approach provided a relatively easy means to study the opinions of a large group of customers in a limited time frame and at a low cost. Also, the respondents could maintain their privacy when answering questions in relation to their financial service utilization and other demographic data.

\section{Measures}

The final questionnaire was developed and modified based on the pilot test. It included three parts with 21 statements designed to assess the seven different components: tangibility, responsiveness, reliability, assurance, empathy, customer loyalty and customer satisfaction. The first part contained 15 statements from the 
SERVQUAL model (Parasuraman et al., 1985) related to customer satisfaction. The second part contained six statements related to customer loyalty and satisfaction (Consuegra et al., 2008). For every variable, we asked the respondents to indicate their agreement with each statement using a seven-point Likert scale ranging from "1-strongly disagree" to "7-strongly agree" based on their experiences, expectations and perceptions. Finally, the third part contained multiple-choice questions related to the demographic profiles of respondents.

Descriptive analysis was used to present a profile of the respondents and to identify the mean and standard deviation of each SERVQUAL, satisfaction and loyalty statement. Factor analysis was applied to determine whether the factors loadings were fragmented to another construct; an orthogonal factor analysis approach (Varimax) was used. The variables in this study are categorized into independent, dependent and mediating variables. Five dimensions in the SERVQUAL model are independent variables; customer satisfaction is the mediating variable, and customer loyalty is the dependent variable; all variables are measured by the multi-item scale.

\section{RESULTS}

\section{Sample and Response Rate}

We sent an email to 150 customers of HSBC through a non-probability, convenience sampling method. Finally, 119 customers returned the questionnaires with a 79\% response rate. The completed questionnaires were used for analysis.

\section{Descriptive Statistics}

The percentage of females (52.1\%) and male (47.9\%) is quite similar, giving less sampling bias. The dominant age groups were 31 to 40 (42.9\%) and 21 to 30 (38.7\%). The majority were white-collar workers (28.6\%), professionals/managers (18.5\%) and salespeople (18.5\%). In addition, $24.4 \%$ of respondents reported an income level of $\$ 15,001$ to $\$ 20,000 ; 20.2 \%, \$ 20,001$ to $\$ 25,000$. Most of the respondents were high school (33.6\%) or college (27.7\%) graduates. Overall, the samples include a balanced number of subjects who should have sufficient knowledge of banking services.

\section{Unidimensionality}

Unidimensionality occurs when one construct underlies a set of items (Gerbing \& Anderson, 1988). It is a fundamental element for confirming the validity of a construct and should be determined before other validation processes (Garver \& Mentzer, 1999). In this study, we tested the unidimensionality of each component factor by first 
looking at the results of a principal component analysis (PCA) in the exploratory factor analysis (EFA) and analyzing the alpha scores (Williams et al., 2009). Factor analysis using PCA and Varimax rotation confirmed scale development and yielded six different factors. Seventeen of the 18 items loaded on 6 factors explaining at least $60 \%$ of the total variance. Table 1 reveals that the results of factor analysis with rotated component matrix can be grouped into six components. The factors were labeled "customer loyalty" (factor 1), "assurance" (factor 2), "reliability" (factor 3), "empathy” (factor 4), "tangibility" (factor 5) and "responsiveness" (factor 6). All of the Cronbach's alpha values were higher than 0.70 , and most of factor loadings of the observable items were over 0.55 , which were regarded as strong items in the construct. Only one item in the model had a factor loading below 0.51 , so it was considered as a weak item in the construct. Therefore, the statement "Sufficient staffs are available to provide customers banking services" was eliminated to increase the reliability and content validity. Moreover, the total variance was high at 82.5 percent, indicating initial evidence of unidimensionality.

Table 2 presents the results of factor analysis for the variable of customer satisfaction. Cronbach's alpha values were higher than 0.70 , and all items in the model had a factor loading over 0.70 ; thus, they were regarded as strong items in the construct. These items formed a dependent variable representing customer satisfaction.

\section{Multiple Regression}

With reference to the theoretical framework presented in Figure 1, the relationships of SERVQUAL, customer satisfaction and loyalty were examined by regression analysis. Results are summarized in Table 3. All five SERVQUAL dimensions were significantly related to customer satisfaction at the level of $p<0.01$, except empathy with $p<0.1$. Customer satisfaction was also significantly related to loyalty at the level of $p<0.01$. The R-square values of customer satisfaction and customer loyalty were 0.270 and 0.367 , respectively, which indicate a moderate level of explanation of both dependent variables by the independent variables included in our regression model. Our results support all six hypotheses. 


\section{Table 1 Six Factors Derived from Rotated Component Matrix}

\begin{tabular}{lllllll}
\hline Variables and Questionnaire Items & \multicolumn{7}{c}{ Component } \\
& 1 & 2 & 3 & 4 & 5 & 6 \\
\hline
\end{tabular}

Customer Loyalty (Cronbach's alpha $=.895$ )

I will prioritize HSBC when selecting the same type of banking service among $\quad .874$ banks.

I will continue to choose HSBC's products or services.

I agree that I am a HSBC's loyal customer.

Assurance (Cronbach's alpha $=.871$ )

The bank can provide customers the services as promised. $\quad .766$

$\begin{array}{ll}\text { The bank can provide accurate service to customers. } & .723\end{array}$

The bank can honor their commitments.

Reliability (Cronbach's alpha $=.884$ )

$\begin{array}{ll}\text { Customers can feel a sense of secure during the transaction process. } & .721\end{array}$

Banking service can increase customers’ confident and trust in quality services. $\quad .672$

Staff can provide customers prompt and appropriate services. $\quad .656$

Empathy (Cronbach's alpha $=.855$ )

$\begin{array}{ll}\text { Staffs are knowledgeable to solve customers’ problems. } & .746\end{array}$

Staffs have the enthusiasm to understand customer needs.

Staffs consider customer needs in the first place. $\quad .619$

Tangibility (Cronbach's alpha $=.872$ )

The equipment of bank is sufficient and visible for customers' usage.

The bank facilities and designs make customers feel comfortable $\quad .657$

Sufficient staffs are available to provide customers banking services.

Responsiveness (Cronbach's alpha $=.889$ )

Staffs can provide customers precise personal services. $\quad .721$

Staffs can understand customers' needs.

Staffs are helpful to customers. $\quad .556$

Notes: Extraction Method: Principal Component Analysis.

Rotation Method: Varimax with Kaiser Normalization.

a. Rotation converged in 7 iterations.

Table 2 Rotated component matrix of customer satisfaction

\section{Variables and Questionnaire Items}

Customer satisfaction (Cronbach's alpha $=.824$ )

I feel satisfied when using HSBC Banking services

I am satisfied with the overall service quality of HSBC

Overall, I have a good and positive impression towards HSBC

Notes: Extraction Method: Principal Component Analysis.

\section{Component}

1

.786

a. 1 components extracted. 
Table 3 Regression results (Unstandardized coefficient $B$ )

\begin{tabular}{lcc}
\hline \multirow{2}{*}{ Independent Variables } & \multicolumn{2}{c}{ Dependent Variables } \\
& Customer Satisfaction & Customer Loyalty \\
\hline Tangibility & $.228^{* *}$ & \\
Responsiveness & $.234^{* *}$ & \\
Reliability & $.229^{* *}$ & \\
Assurance & $.293^{* *}$ & $.606^{* *}$ \\
Empathy & $.157^{*}$ & \\
Customer satisfaction & & .367 \\
& & .362 \\
R-Square & .270 & 67.837 \\
Adjusted R-Square & .238 & \\
F Value & 8.363 & \\
\hline
\end{tabular}

Notes: $n=119$

** Significant at $\mathrm{p}<0.01$

* Significant at $\mathrm{p}<0.1$

\section{DISCUSSION}

This study presents the interrelationships among service quality, customer satisfaction and customer loyalty in the retail banking sector in Hong Kong. The five SERVQUAL dimensions show positive relationships with customer satisfaction. This study also suggests that SERVQUAL is a suitable instrument for measuring the retail banking service quality in Hong Kong. Therefore, bank managers can use this instrument to assess bank service quality in Hong Kong and may even use it in other Asian countries. Service quality should be emphasized for maintaining and improving customer satisfaction.

Among the five SERVQUAL dimensions, empathy, tangibility, responsiveness, reliability, and assurance were found to be significant predictors of customer satisfaction. This implies that these five dimensions are most important to Hong Kong customers. The results also show that tangibility has a positive influence on customer satisfaction. This can be explained by customer impressions of tangible factors in terms of physical facilities, equipment and appearance of personnel. Customers may assess bank facilities and designs, sufficiency and visibility of equipment, and the appearance of the employees in banks. Responsiveness is also a key success factor in the Hong Kong banking sector. The willingness of service providers to assist and provide prompt services to customers is very important to customer evaluation of banks. The results show that responsiveness has a positive influence on customer satisfaction. Customers are satisfied with the personal services provided and service personnel who understand their needs. Reliability can also positively affect customer 
satisfaction in the retail banking sector in Hong Kong. This represents the values perceived by customers in relation to the capital they have invested. Data demonstrate that customers are quite satisfied with the services provided by banks as promised and the security level of the transaction process. Customers are confident that banks can realize the promised services so that they can consume products and services with trust. Assurance is another factor emphasized by customers in Hong Kong. The degree of trust and confidence that customers feel about the banking services greatly depends on the services quality provided by the employees of banks. According to the research results, assurance has a positive influence on customer satisfaction. This result can be explained by the excellent and competent services that the bank staff provide. Customers feel that banks can honor their commitments and hence are confident in using bank products. Finally, empathy has the least importance in consumers' mind. Results shows that empathy is positively related to customer satisfaction, but customers perceive a low degree of interaction with employees in banks providing personalized service. The bank reflects a weak ability to fulfill customers' concerns regarding individual needs, such as solving customers' enquiries and problems.

Although long-term orientation and personal connections are dominant in East Asian countries such as Taiwan, Japan, Singapore, Malaysia, Indonesia, Korea Thailand and Hong Kong (Hofstede, 1994; Luo, 1997; Ramasamy et al., 2006; Theingi et al., 2008), each of these places has its own unique business culture. Because of its colonial history, Hong Kong has established a well-developed political organization, education system and way of life intensely influenced by Western culture (Lee, 2003). People are more practical in Hong Kong and can perform tasks by themselves effectively. This may be the reason why empathy was found to be least important to customer satisfaction.

The overall satisfaction of HSBC customers has a mediating effect on the relationship between service quality dimensions (tangibles, reliability, responsiveness, empathy and assurance) and HSBC customer loyalty. This result is consistent with research by Caruana (2002), Butcher, Sparks, and O'Callaghan (2001), Ehigie (2006) and Lam and Burton (2006). This study provides motivation and insights to managers in the retail banking industry to further emphasize increasing customer satisfaction. According to Fogli (2006), companies have adopted customer focus as a strategy to link themselves more closely with their changing environment in recent years. Banks must identify potential customers, determine their needs, and then develop and deliver products and services to meet their needs effectively. Levesque and 
McDougall (1996) point out that a good employee-customer relationship can increase the satisfaction level and that problem recovery is essential to maintain customer satisfaction.

Loyalty is the direct result of customer satisfaction, which is greatly influenced by the value of services provided to customers. The performance of customer service providers requires interaction with a customer, which leads to a focus on employee relations and customer service to achieve corporate goals. Indeed, staff attitudes directly influence customer experience, and happy employees can help to improve customer satisfaction. Thus, the increasing satisfaction level leads to a decrease in operating and servicing costs, which provides an opportunity to expand existing and new products and services. Staff performance can be strengthened by treating them as an asset to increase intimacy with customers. According to Ndubisi (2006), customer satisfaction can be achieved by offering personalized, flexible and adjustable services to suit the needs of customers. Bilateral communication is another essential element to satisfy customers and retain loyalty. Although customer service has been evaluated for years, banks must continue to keep up with changing customer behaviors and the nature of the banking industry itself.

\section{Practical Implications}

This study finds that HSBC is evaluated positively by respondents in general, but continuous improvements are recommended to maintain a competitive edge. One managerial implication is the need for banks to consider recruitment and human resources programs. First, banks should ensure that employees are able to provide professional services. Staffs are assets of a corporation and the key to building bridges with customers. Cook (2008) notes that training and development help organizations to be more flexible, proactive and customer-focused in the face of fierce competition and serve as a prime motivational tool. A strong infrastructure of providing professional services including knowledge, skills and attitudes can be adopted to encourage employees to become empowered, so that they can truly read customers' needs and gain work satisfaction by providing correlated services. Moreover, banks should pay extra attention to customer needs. Customer satisfaction is improved when the service provided surpasses the perceived value of customers. An exchange of information is essential to understand changing customer needs and behaviors so that corporations can customize products for individuals. Finally, banks have to protect customer privacy and avoid revealing any data to marketers. Customers are more sensitive to privacy protection after the legal case of Octopus Holding Ltd. selling 
customer personal data in Hong Kong (Cagape, 2010). Corporations with good credit can build the confidence of customers to share important information and to consider repeat purchases.

\section{Future Research}

Several issues associated with the limited time frame and cost in this study require further research considerations. Future research should concentrate on a larger sample size and all types of retail banks in Hong Kong. Moreover, e-business is a major trend in the world. Banks have to utilize Internet technologies to improve productivity or profitability. To be more successful, banks should prepare for changes in technological advances. Therefore, e-business or technology should be incorporated as a factor to measure service quality in future research.

\section{REFERENCES}

Angur, M. G., Nataraajan, R. \& Jahera, J. S. (1999). Service quality in the banking industry: An assessment in a developing economy. International Journal of Bank Marketing, 19(3), 1116-1123. http://dx.doi.org/10.1108/02652329910269211

Arasli, H., Smadi, S. M. \& Katircioglu, S. T. (2005). Customer service quality in the Greek Cypriot banking industry. Managing Service Quality, 15(1), 41-56. http://dx.doi.org/10.1108/09604520510575254

Berry, L. L., Bennet, D. R. \& Brown, C. W. (1989). Service Quality: A Profit Strategy for Financial Institutions. Homewood, IL: Dow-Jones-Irwin.

Butcher, K., Sparks, B. \& O'Callaghan, F. (2001). Evaluative and relational influences on service loyalty. International Journal of Service Industry Management, 12 (3/4), 310-327. http://dx.doi.org/10.1108/09564230110405253

Cagape, E. W., Asian correspondent.com, (2010, August 5). Octopus card admits making money selling personal data to third parties. Retrieved from http://asiancorrespondent.com/38323/octopus-card-admits-makingmoney-selling-personal-data-to-third-parties/

Caruana, A. (2002). Service loyalty: The effects of service quality and the mediating role of customer satisfaction. European Journal of Marketing, 36 (7/8), 811-828. http://dx.doi.org/10.1108/03090560210430818

Caruana, A., Money, A. H. \& Berthon, P. R. (2000). Service quality and satisfaction: The moderating role of value. European Journal of Marketing, 34 (11/12), 1338-1352. http://dx.doi.org/10.1108/03090560010764432 
Censtatd, Census and Statistics Department, (2011, November 11). Gross Domestic Product (GDP) by economic activity - Percentage contribution to GDP at basic prices. Retrieved from http://www.censtatd.gov.hk/hong_kong_statistics/ statistical_tables/index.jsp?charsetID=1\&tableID=036\&subjectID=

Censtatd, Census and Statistics Department, (2011, November 29). Selected statistics for all establishments in the information and communications, financing and insurance, professional and business services sections. Retrieved from http://www.censtatd.gov.hk/hong_kong_statistics/statistical_tables/index.jsp?char setID=1\&tableID=091\&subjectID $=5$

Churchill, G. \& Surprenant, C. (1982). An investigation into the determinants of customer satisfaction. Journal of Marketing Research, 19 (4), 491-504. http://dx.doi.org/10.2307/3151722

Consuegra, D. M., Molina, A. \& Esteban, Á. (2008). Market driving in retail banking. The International Journal of Bank Marketing, 26 (4), 260-274. http://dx.doi.org/ $10.1108 / 02652320810884795$

Cook, S. (2008). Customer care excellence: How to create an effective customer focus ( $5^{\text {th }}$ ed. pp. 280). London, England: Kogan Page.

Cronin, J. J., Brady, M. K. \& Hult, G. T. M. (2000). Assessing the effects of quality, value, and customer satisfaction on consumer behavioral intentions in service environment. Journal of Retailing, $76 \quad$ (2), 193-218. http://dx.doi.org/10.1016/S0022-4359(00)00028-2

Ehigie, B. O. (2006). Correlates of customer loyalty to their banks: A case study in Nigeria. International Journal of Bank Marketing, 24 (7), 494-508. http://dx.doi.org/10.1108/02652320610712102

Fogli, L. (2006). Customer Service Delivery: research and best practices. $\left(1^{\text {st }}\right.$ ed. pp. 135-172), San Francisco, CA: Jossey-Bass.

Forbes, (2011, March). Global 2000 leading companies. Forbes. Retrieved from http://www.forbes.com/companies/hsbc-holdings/

Garver, M. \& Mentzer, J. T. (1999). Logistics research methods: Employing structural equation modeling to test for construct validity. Journal of Business Logistics, 20 (1), 33-57.

Gerbing, D. W. \& Anderson, J. C. (1988). An updated paradigm for scale development incorporating unidimensionality and its assessment. Journal of Marketing Research, 25(2), 186-192. http://dx.doi.org/10.2307/3172650

Gremler, D. D. \& Brown, S. W. (1996). Service loyalty: its nature, importance and implications. Proceedings of American Marketing Association, 171-180. (pp. 
171-180). New York, U.S.A.: International Service Quality Association Inc. (ISQA) c/o Business Research Institute, St John's University

Hofstede, G. (1994). Business Cultures. The Unesco Courier, 47(4), 12-16. HSBC, The Hongkong and Shanghai Banking Corporation Limited, Retrieved from http://www.hsbc.com

Kang, G. D. \& James, J. (2004). Service quality dimensions: An examination of Gronroos's service quality model. Managing Service Quality, 14(4), 266-277. http://dx.doi.org/10.1108/09604520410546806

Kotler, P. \& Armstrong, G. (1999). Principles of Marketing. Upper Saddle River, NJ: Prentice Hall.

Kumar, M., Kee, F. T. \& Charles, V. (2010). Comparative evaluation of critical factors in delivering service quality of banks: An application of dominance analysis in modified SERVQUAL model. International Journal of Quality and Reliability Management, 27 (3), 351-377. http://dx.doi.org/10.1108/02656711011023320

Ladhari, R. (2009). A review of twenty years of SERVQUAL research. International Journal of Quality and Service Sciences, 1 (2), 172-198. http://dx.doi.org/10.1108/17566690910971445

Lam, R. \& Burton, S. (2006). SME banking loyalty (and disloyalty): a qualitative study in Hong Kong. International Journal of Bank Marketing, 24(1), 37-52. http://dx.doi.org/10.1108/02652320610642335

Lau, M. M., Chang, M. T., Moon, K. L. \& Liu, W. S. (2006). The brand loyalty of sportswear in Hong Kong. Journal of Textile and Apparel, technology and management, 5 (1), 1-13.

Lee, C. Y. (2003). Do traditional values still exist in modern Chinese societies?. Asia Europe Journal, 1 (1), 43-59. http://dx.doi.org/10.1007/s103080200001

Leung, C. S. \& To, C. K. M. (2001). Measuring perceived service quality of fashion stores: A test-retest reliability investigation. Journal of Fashion Marketing and Management, 5 (4), 324-329. http://dx.doi.org/10.1108/EUM0000000007294

Levesque, T. \& McDougall, G. (1996). Determinants of customer satisfaction in retail banking. International Journal of Bank Marketing, 14 (7), 12-20. http://dx.doi.org/10.1108/02652329610151340

Lo, L. K., Osman, M., Ramayah, T. \& Rahim, M. (2010). The impact of service quality on customer loyalty: A study of banks in Penang, Malaysia. International Journal of Marketing Studies, 2 (2), 57-66. Retrieved from http://www.ccsenet.org/journal/index.php/ijms/article/view/8110 
Luo, Y. (1997). Guanxi: principles, philosophies, and implications. Human Systems Management, 16 (1), 43-51. http://dx.doi.org/10.3233/HSM-1997-16106

Malhotra, N. \& Mukherjee, A. (2004). The relative influence of organisational commitment and job satisfaction on service quality of customer-contact employees in banking call centres. Journal of Services Marketing, 18 (3), 162-174. http://dx.doi.org/10.1108/08876040410536477

Mengi, P. (2009). Customer satisfaction with service quality: An empirical study of public and private sector banks. Journal of Management Research, 8 (9), 7-17.

Ndubisi, N. O. (2006). A structural equation modeling of the antecedents of relationship quality in the Malaysia banking sector. Journal of Financial Services Marketing, 11(2), 131-141. http://dx.doi.org/10.1057/palgrave.fsm.4760033

Neal, W. D. (1998). Satisfaction be damned, value drives loyalty. Paper presented at the ARF Week of Workshops, New York. Paper retrieved from http://www.sdr-consulting.com/article4.html

Parasuraman, A., Berry, L. L. \& Zeithaml, V. A. (1985). A conceptual model of service quality and its implications for future research. Journal of Marketing Research, 49 (4), 41-48. http://dx.doi.org/10.2307/1251430

Parasuraman, A., Berry, L. L. \& Zeithaml, V. A. (1988). SERVQUAL: A multiple-item scale for measuring consumer perceptions of service quality. Journal of Retailing, 64(1), 12-40.

Ramasamy, B., Goh, K. W. \& Yeung, M. C. H. (2006). Is guanxi (relationship) a bridge to knowledge transfer? Journal of Business Research, 59 (1), 130-139. http://dx.doi.org/10.1016/j.jbusres.2005.04.001

Reichheld, F. F. \& Sasser, W. E. (1990). Zero defections: Quality comes to service. Harvard Business Review, 68 (5), 105-111.

Rust, R. T. \& Zahorik, A. J. (1993). Customer satisfaction, customer retention and market share. Journal of Retailing, 69 (2), 193-215. http://dx.doi.org/10.1016/0022-4359(93)90003-2

Ryan, M. J., Rayner, R. \& Morrison, A. (1999). Diagnosing customer loyalty drivers.

Marketing Research, 11(2), 18-26.

Siddiqi, K. O. (2010). Interrelationships between service quality attributes, customer satisfaction and customer loyalty in the retail banking sector in Bangladesh. Paper presented at the International Trade and Academic Research Conference, London.

Smith, S. (1998). How to create a plan to deliver great customer service. In Zemke, R. \& Woods, J. A. (Eds.). Best Practices in Customer Service. New York, NY: 


\section{AMACOM.}

Teich, I. (1997). Holding on to customers: The bottom-line benefits of relationship building. Bank Marketing, 29(2), 12-13.

The Hong Kong Association of Banks, (2010, June 24). Member Banks. Retrieved from http:/www.hkab.org.hk/DisplayWhatsNewsAction.do

The Standard, (2011, September 10). HK in top five of world bank rankings. Retrieved from http://www.thestandard.com.hk/breaking_news_detail.asp?id=5708\&

Theingi, Purchase, S. \& Phungphol, Y. (2008). Social capital in Southeast Asian business relationships. Industrial Marketing Management, 37(5), 523-530. http://dx.doi.org/10.1016/j.indmarman.2007.09.014

Van Iwaarden, J., van der Wiele, T., Ball, L. \& Millen, R. (2003). Applying SERVQUAL to Web sites: An exploratory study. International Journal of Quality $\begin{array}{llll}\text { and Reliability } & \text { Management, } & & \text { (8), }\end{array}$ http://dx.doi.org/10.1108/02656710310493634

Wernerfelt, B. (1991). Brand loyalty and market equilibrium. Marketing Science, 10 (3), 229-245. http://dx.doi.org/10.1287/mksc.10.3.229

Williams, Z., Ponder, N. \& Autry, C. W. (2009). Supply chain security culture: Measure development and validation. The International Journal of Logistics Management, 20 (2), 243-260. http://dx.doi.org/10.1108/09574090910981323

Yee, R. W. Y., Yeung, A. C. L. \& Cheng, T. C. E. (2010). An empirical study of employee loyalty, service quality and firm performance in the service industry. International Journal of Production Economics, 124(1), 109-120. http://dx.doi.org/10.1016/j.ijpe.2009.10.015

Yoon, S. \& Suh, H. (2004). Ensuring IT consulting SERVQUAL and user satisfaction: A modified measurement tool. Information Systems Frontiers, 6 (4), 341-351. http://dx.doi.org/10.1023/B:ISFI.0000046376.10364.16

Zaim, H., Bayyurt, N. \& Zaim, S. (2010). Service quality and determinants of customer satisfaction in hospitals: Turkish experience. The International Business \& Economics Research Journal, 9(5), 51-58.

Zeithaml, V. A., Berry, L. L. \& Parasuraman, A. (1996). The behavioral consequences of service quality. Journal of Marketing Research, 60(2), 31-46. http://dx.doi.org/10.2307/1251929

Zeithaml, V. A., Parasuraman, A. \& Berry, L. L. (1990). Delivering Quality Service: Balancing Customer Perceptions and Expectations. New York: NY: Free Press. 
